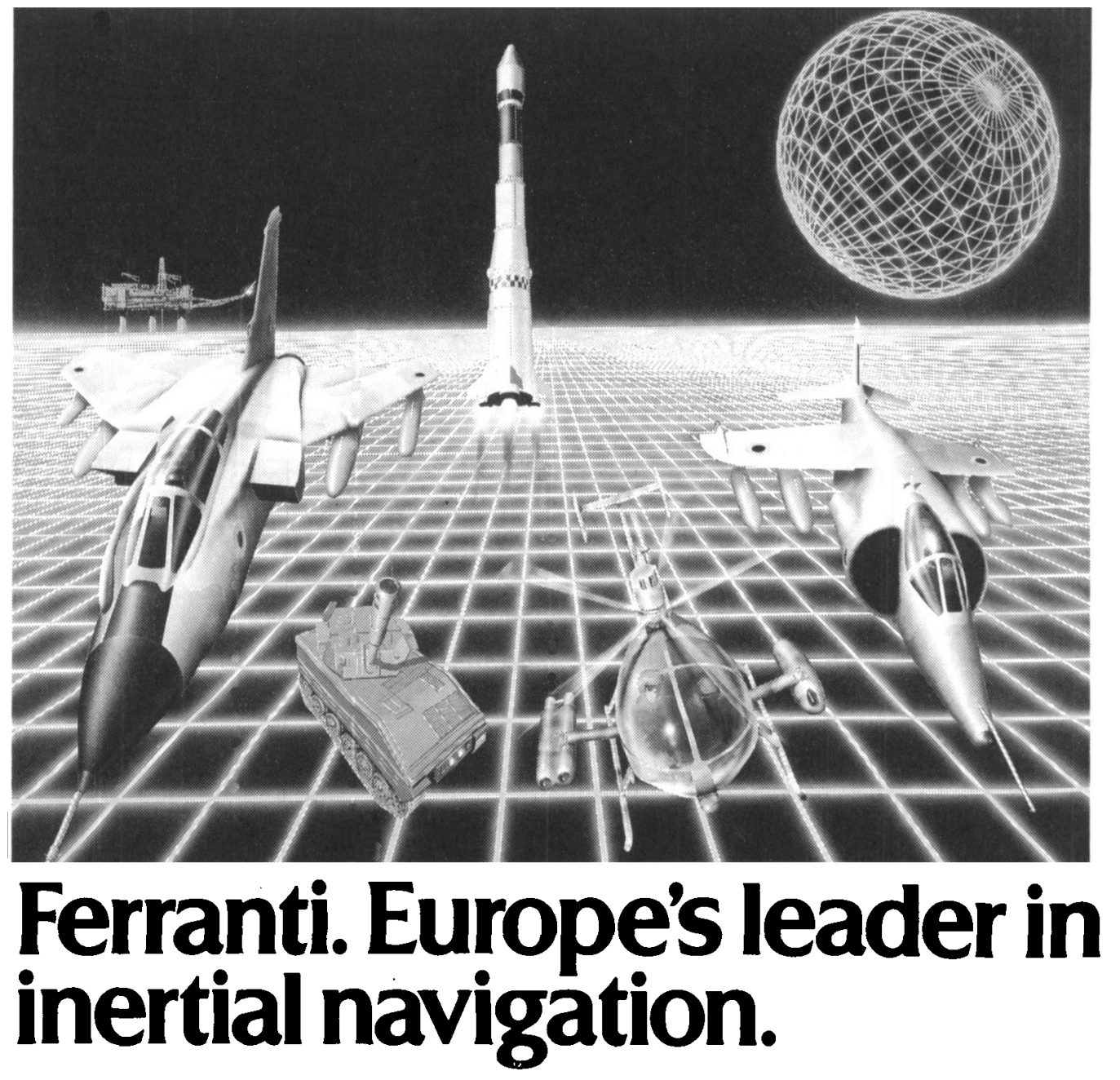

The leading position of Ferranti in defence electronics is especially evident in our navigation systems.

Highly developed resources and wide experience in this field have given us a notable record of success.

Ferranti inertial navigation systems are currently beingused by the Royal Air Force and by the air forces of Germany, Italy and Japan in the Jaguar, Harrier, Tornado, Nimrod and Mitsubishi F-1 aircraft and have recently been selected for the Harrier GR5 programme. They also feature in the Royal Navy and Indian Navy Sea Harriers.

The FIN 11102 -gimbal inertial system has been specially selected for the Hughes 530 MG helicopter.

The FIN 3020 Ring Laser Strapdown Inertial Nav/Attack system is being developed for the Ministry of Defence.

Other Ferranti successes include integrated weapon aiming systems, inertial space guidance systems, survey equipment, and precision instruments such as gyroscopes, compasses and rotary scanners.

Ferranti Defence Systems Limited, Navigation Systems Department, Silverknowes, Edinburgh EH4 4AD Telephone: 031-332 2411 Telex: 727101

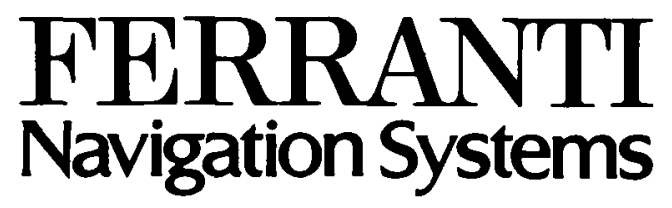

Jnl. of Navigation, 39, 2

(i) 


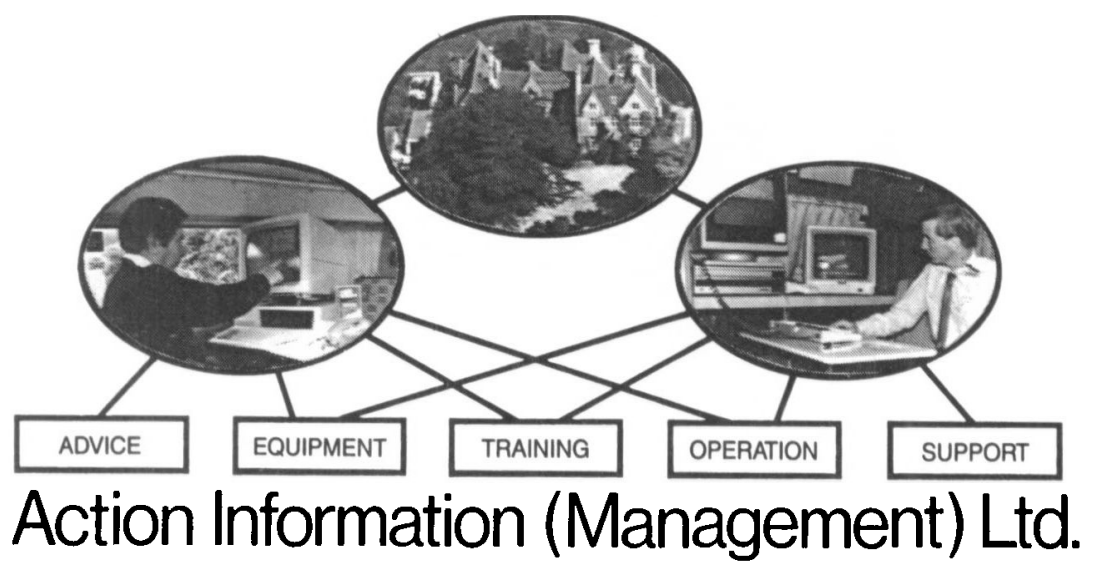

- Nothing is better than maps for displaying present position of vehicle fleets and destinations

- The AIM approach uses Interactive Video to display maps of any area accurately overlayed with information on resource location

- Systems designed for the Emergency Services:

- use the IBM PC AT

- have the capacity for the inclusion of appropriate decision support software and the development of a suitable Expert System

- meet the needs of firms having CIMAH responsibilities

- The MAPS IN ACTION workstation shown at Nav '85 is based on the popular Acorn BBC hardware and software

- it is an ideal display for Automatic Vehicle Location Systems which use the National Grid

We are working with the Research division of the Home Office to evaluate the utility of these systems

To discuss these points further contact Michael Page NOW at: ACTION INFORMATION

(MANAGEMENT) Ltd

Hilperton

Wiltshire

BA14 7QY

Tel (02214) 2206. Telex 444337

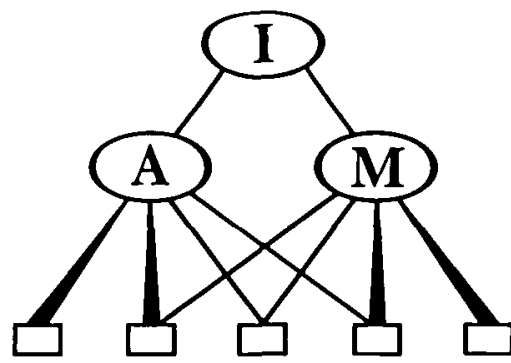

Action Information (Management) Ltd.

NB We run two-day courses introducing 'Interactive Video in Crisis Management'. Full information is available on request. 


\section{| | | | | |MDL | | | | | |}

MEASUREMENT DEVICES LIMITED

\section{ARE GETTING THE MESSAGE} from space

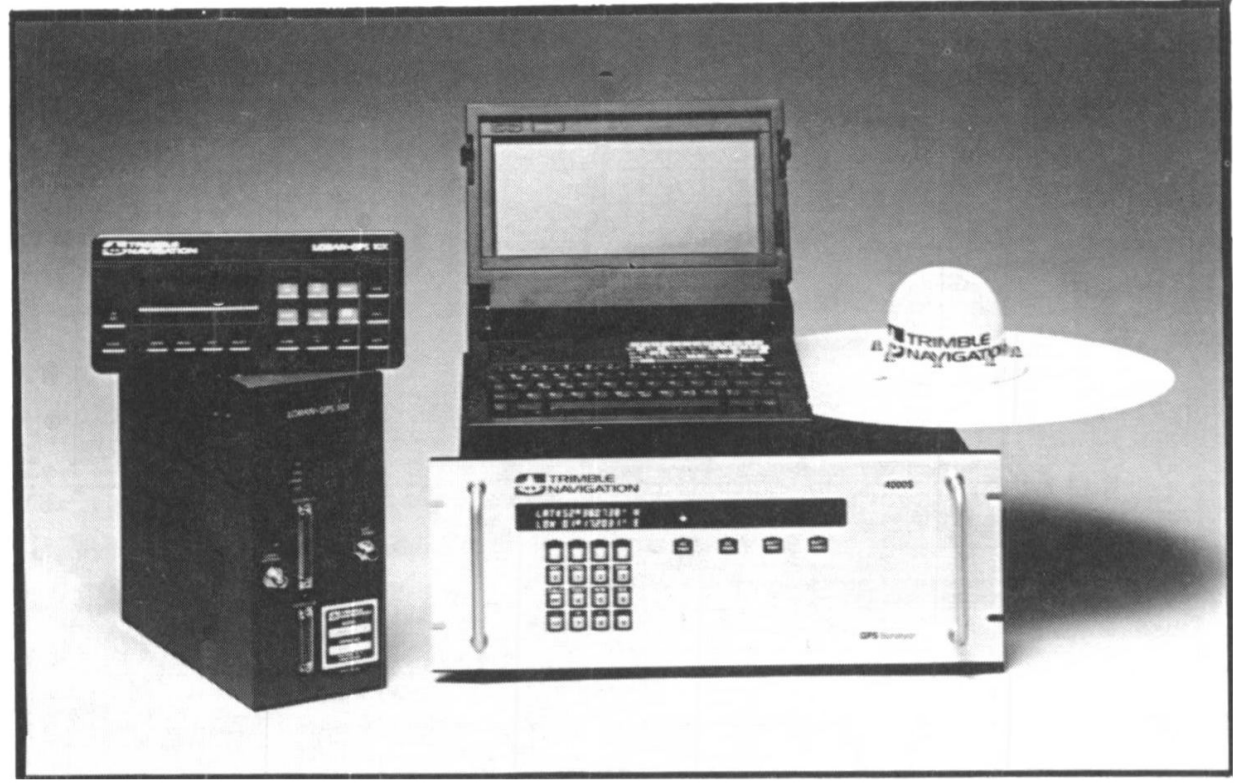

Measurement Devices Ltd, as representatives for TRIMBLE NAVIGATION INC, have available GPS Receivers for all applications, from high accuracy Geodetic units capable, with BASELINER (TM) software, of producing millimetric accuracy, through very accurate dynamic positioning receivers, to navigation units integrated with LORAN $\mathrm{C}$.

For further information, please contact our Norwich office.

Capitol House

Heigham Street

$\mathrm{NORWICH}$

Norfolk NR2 4TE

Tel: (0603) 630031

Telex: 975205 MDLAN
Silverburn Crescent

Bridge of Don Industrial Estate ABERDEEN

Scotland AB2 8EW

Tel: (0224) 824141

Telex: 739506 MDLAB 


\section{...RELIABLE COMMUNICATIONS}

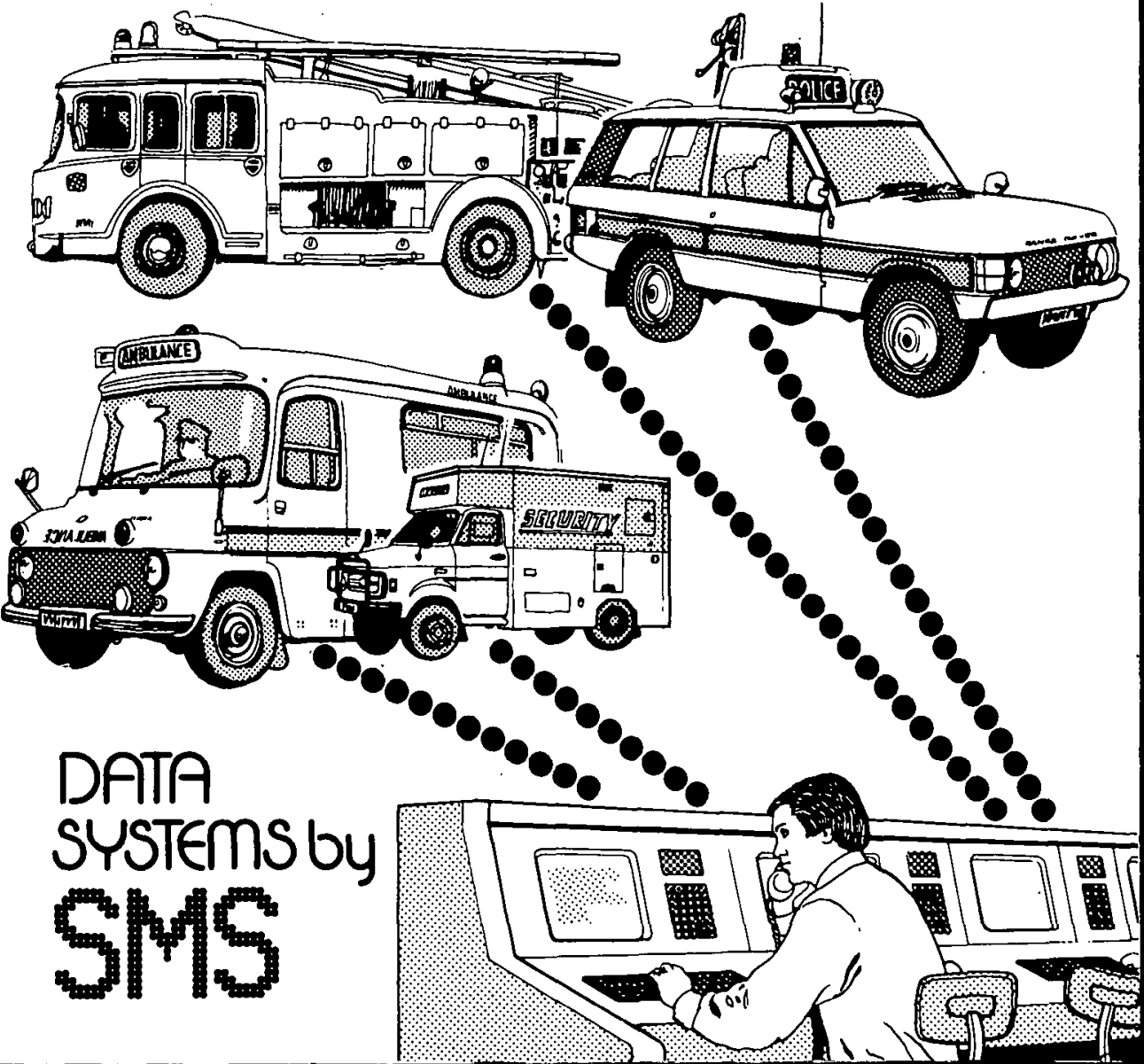

\section{make a world of difierence
to communications}

DATA SYSTEMS:

Automatic message reception; 2-way data communication between mobiles and base computers; automatic vehicle location; radio mobile telemetry; radio coverage surveys.

\section{DISPLAY SYSTEMS:}

Custom-built modular displays - from single digit numerics to complex alphanumerics with animation and microcomputer control.

SMS

SPECTRONICS MICRO SYSTEMS LTD

Viking Way, Bar Hill, Cambridge CB3 8EL, England.

Telephone: Crafts Hill (0954) 80888. Telex: 818873 SMS G 


\section{THE INTERNATIONAL HYDROGRAPHIC REVIEW}

Half-yearly, 160 pages (approx.) $18 \times 27 \mathrm{~cm}$. Price 120 French francs* Yearly subscription 215 French francs*

Among the papers of interest in the January 1986 issue are:

- Survey tasks arising from the UN Convention on the law of the Sea (J. A. L. MYRES)

- Automation in hydrographic survey - The HYDRAUT solution

- Ocean charting

(P. G. SLUITER)

(W. F. WATSON)

PUBLISHED BY THE

INTERNATIONAL HYDROGRAPHIC BUREAU

7, av. President J. F. Kennedy,

B.P. $345-\mathrm{MC} 98000$ MONACO

The Bureau also publishes monthly

THE INTERNATIONAL HYDROGRAPHIC BULLETIN

A bilingual journal-English and French-giving news of hydrographic activities worldwide. Lists in detail charts published by Member States of the International Hydrographic Organization, and contains a selective bibliography of recent works in the fields of hydrography, descriptive oceanography, navigation, cartography, etc.

Approx. 30 pages, $21 \times 30 \mathrm{~cm}, 13.50$ French francs per copy* Yearly subscription: 135 French francs*

* Postage extra 
VEHICLE LOCATION TRACKING AND CONTROL

NATIONAL COVERAGE USING RACAL RESOURCES

RACAL supplies and operates land, sea and air positioning systems using RACAL DECCA NAVIGATOR, RACAL PULSE/8, RACAL HYPERFIX and LORAN.

CONTACT: Racal Positioning Systems Ltd., Kingston Road, Leatherhead, Surrey KT22 7ND, United Kingdom. Tel: 0372.375375

Telex: 928437 RPSLD 


\section{THE ROYAL INSTITUTE OF NAVIGATION}

$\mathrm{T}$ HE OBJECT of the Institute is to unite in one body those who are concerned with or who are interested in the science and art of navigation. Membership is not restricted to those who hold professional qualifications, but is open to others who wish to further the aims of the Institute.

By coordinating the knowledge and achievements of marine and air navigators, scientists and those associated with the development and production of navigational equipment, the work of the Institute is directed towards raising the standard of navigation. In the field of education it is the aim of the Institute to bring practical navigators into contact with teachers and research workers to increase a common appreciation of the issues involved. It is an object of the Institute to encourage research in equipment and methods; through its publications it gives a wide circulation to original work on navigation so that new developments and suggestions can be appreciated by those most directly concerned with them.

The activities of the Institute include the holding of monthly meetings to discuss specific problems, the publication of a Journal and of other works concerned with different aspects of navigation, and such other activities as the Council may deem necessary to promote knowledge in navigation and its associated sciences.

The Journal of Navigation is issued free to all Members and contains a full account of the Institute's proceedings. It prints the papers which are presented at meetings, together with their ensuing discussion, and other original papers contributing to the science of navigation. It also contains a record of current navigational work, reviews of important books, and general papers of interest to navigators and those with similar interests.

The work of the Institute is coordinated with that of similar societies abroad, whose proceedings are available to members.

Membership. There are five classes of membership of the Institute :

(I) HONORARY MEMBERS, who shall be distinguished persons upon whom the Council may see fit to confer an honorary distinction.

(2) FELlows, who shall be members, of at least three years' standing who, in the opinion of the Council, have made a contribution of value to navigation.

(3) MEMBERs, who shall be persons over twenty-one years of age who can satisfy the Council of their interest in navigation.

(4) STUDENT MEMBERs, who shall be persons under twenty-five years of age studying with a view to making navigation, or an allied interest, their career.

(5) CORPORATE MEMBers, who shall be companies, universities, navigation schools, government departments and other organizations, here and abroad, who are directly or indirectly interested in the science of navigation. Corporate Members are entitled to send representative to all Institute meetings and to receive six copies of the Journal, and other publications. They are encouraged to take an active part in the Institute's work. Applications should be sent by letter addressed to the Director.

Subscriptions. Annual subscriptions to the Institute are payable in advance as follows :

Members and Fellows

Student Members .

Corporate Members .

$£ 23.00$

$\pm 5.00$

£ 150.00

The Institute's financial year begins on I July. Members in any category who are elected after I January in any year are only due for one half of their subscription until i July, when the full subscription for the next year becomes due. 
CAMBRIDGE UNIVERSITY PRESS

The Pitt Building, Trumpington Street, Cambridge CB2 IRP

32 East $57^{\text {th }}$ Street, New York, NY 10022 , USA

Io Stamford Road, Oakleigh, Melbourne 3166, Australia

Printed in Great Britain by the University Press, Cambridge 